\title{
Anatomy of soft body of Pugilina cochlidium (Linnaeus, 1758) and P. erecta (Vermeij \& Raben, 2009) (Neogastropoda: Melongenidae) from Thondi Coast-Palk Bay in Tamil Nadu, India
}

\author{
P. De los Ríos-Escalante ${ }^{a, b}$ (D), C. Ragunathan ${ }^{c}$, L. Kanagu ${ }^{c}$ (D) and C. Stella ${ }^{c *}$ (D) \\ aDepartamento de Ciencias Biológicas y Químicas, Facultad de Recursos Naturales, Universidad Católica de \\ Temuco - UCTemuco, Casilla 15-D, Temuco, Chile \\ bNúcleo de Estudios Ambientales, Universidad Católica de Temuco - UCTemuco, Casilla 15-D, Temuco, Chile \\ 'Department of Oceanography and Coastal Area Studies, Alagappa University, Thondi Campus, 623409, Tamil Nadu, India \\ *e-mail: stella2004@rediffmail.com; stella2004@alagappauniversity.ac.in
}

Received: July 13, 2019 - Accepted: December 10, 2019 - Distributed: May 31, 2021

(With 3 figures)

\begin{abstract}
The species of Pugilina cochlidium (Linnaeus, 1758) and P. erecta (Vermeij \& Raben, 2009) has been studied in the present study. The female can be differentiated from the male by the absence of the cephalic penis and a complicated genital aparatus visible through the mantle skirt in both the sexes. In other aspects of the external features of female are quite to males. In both species the digestive system was similar with few differences in structure between each other. It consists of buccal mass, proboscis, salivary glands, accessory salivary glands, oesophagus, stomach, intestine, rectum and anus. The nervous system in both $P$. cochlidium and P. erecta is constituted by six ganglia which forms the circumoesophgeal ganglionic ring. Among the neogastropods there is a similarity in the organization of the reproductive systems. The female reproductive system is more complicated than that of male. The sexes are separated in these two species. The gross morphology of the reproductive system of $P$. cochlidium and $P$. erecta was almost similar. The present study aims to describe the digestive system, nervous system and reproductive system of two gastropods species $P$. cochlidium and $P$. erecta.
\end{abstract}

Keywords: gastropoda, melongenidae, Pugilina cochlidium, P. erecta, anatomy.

\section{Anatomia do corpo mole de Pugilina cochlidium (Linnaeus, 1758) e $\boldsymbol{P}$. erecta (Vermeij \& Raben, 2009) (Neogastropoda: Melongenidae) de Thondi Coast- Palk Bay em Tamil Nadu, na Índia}

\begin{abstract}
Resumo
As espécies de Pugilina cochlidium (Linnaeus, 1758) e P. erecta (Vermeij \& Raben, 2009) foram tomadas no presente estudo. A fêmea pode ser diferenciada do macho pela ausência do pênis cefálico e um complicado complexo genital visível através da saia do manto em ambos os sexos. Em outros aspectos das características externas da fêmea são bastante semelhantes aos dos machos. Em ambas as espécies, o sistema digestivo era semelhante, com poucas diferenças de estrutura entre si. Consiste em massa bucal, probóscide, glândulas salivares, glândulas salivares acessórias, esôfago, estômago, intestino, reto e ânus. O sistema nervoso em $P$. cochlidium e $P$. erecta é constituído por seis gânglios que formam um anel ganglionar circunoesofágico. Entre os neogastrópodes, há uma semelhança na organização dos sistemas reprodutivos. O sistema reprodutivo feminino é mais complicado que o masculino. Os sexos são separados nessas duas espécies. A morfologia macroscópica do sistema reprodutivo de $P$. cochlidium e $P$. erecta foi quase similar. O presente estudo tem como objetivo descrever o sistema digestivo, sistema nervoso e sistema reprodutivo de duas espécies, $P$. cochlidium e $P$. erecta.
\end{abstract}

Palavras-chave: gastropoda, melongenidae, Pugilina cochlidium, P. erecta, anatomia.

\section{Introduction}

The phylogenetic analyses of the higher classification of neogastropoda have been studied based on the anatomical characters of the digestive system especially on the foregut
(Andrews, 1991; Ball et al., 1997; Benny et al., 1996; Brown, 1969; Carriker et al., 1963, 1967; Carriker and Williams, 1978; Carriker, 1981; Chétatl and Fournié, 1969; 
Greene and Köhn, 1989; Harasewych, 1984; Hou et al., 1990; Kantor and Taylor, 2002; Kantor, 1996; Kantor and Harasewych, 1994; Lus, 1981; Marcus and Marcus, 1962a, b; McLean, 1971; Merdsoy and Farley, 1973; Nylen et al., 1969; Person et al., 1967; Taylor et al., 1993). It is generally accepted the evolution of the order, as well as that of other caenogastropods, was determined mainly by the changes in the anatomy of the digestive system (Kohn, 1983) while similarity of shells is often the result of convergence.

Ponder (1973) studied the anatomy of the digestive system of neogastropoda. Buccinoidea is one of the generally accepted monophyletic groups in neogastropods. Six families are usually included into this superfamily: buccinidae, fasciolariidae, nassariidae, melongenidae, columbellidae and colubrariidae. Carriker (1943) has studied the structure and function of the proboscis in the common oyster drills Urosalpinx cinerea (Say, 1822). Ward (1965) has described the digestive tract and its relation to feeding habits in the stenoglossan prosobranch Coralliophila erosa (Röding, 1798). Houston (1976) has studied the structure and function of neogastropod reproductive systems with special reference to Columbella fuscata G.B. Sowerby, 1832. The anatomy of the various proboscis types has been investigated by Greene and Kohn (1989) and Medinskaya (1992). Medinskaya (1992) has investigated the anatomy of the proboscis walls in neogastropods and its connection with diets and feeding mechanism. Medinskaya (1992) has investigated the anatomy of the proboscis walls in Neogastropods and its connection with diets and feeding mechanism. Taylor et al. (1993) has studied the foregut anatomy, feeding mechanisms, relationships and classification of the Conoidae. Ball et al. (1997) has studied the ontogeny of the pleurembolic proboscis in Nucella lapillus. Numerous studies have been made on various aspects of the digestive system by Fretter and Graham (1962), Wu (1965a), Bhanu et al. (1981), Tagore (1989), Guohua et al. (1990), Andrews (1991), Jaramillo (1991) and Middlefart (1992a, b).

Smith $(1967,1980,1981)$ studied the neogastropod stomach, with notes on the digestive diverticula and intestine. Ponder $(1968,1970)$ studied the anatomical notes on two species of the colubrariidae. Medinskaya (1993, 1999) studied the anatomy of the stomach of some neogastropoda from the offshore zone of the Japan sea. Taylor (1978) and Taylor et al. (1980, 1993) studied the foregut anatomy, feeding mechanisms, relationships and classification of Conoidea (Gastropoda). Tan and Phuah (1999) observed the diet and feeding habits of $P$. cochlidium (Linnaeus, 1758) (Neogastropoda: Melongenidae) in Singapore. Kantor and Tursch (2001) have been observed the feeding of Oliva genus. Kantor and Taylor (2002) studied the foregut anatomy and relationships of raphitomine gastropods. In neogastropod there is a similarity in the organization of the reproductive systems. The works carried out on the reproductive system are the following: Fretter (1941), Fretter and Graham (1962), Purchon (1968), Stephen and Blaber (1970), Houston (1971), Bhanu et al. (1981, 1982), Hawkins and
Hutchinson (1988), Gallardo and Garrido (1989), Hou et al. (1990), Cantillanez et al. (2011), Cantillanez and Avendaño (2013) The present study aims to describe the digestive system, nervous system and reproductive system of two species $P$. cochlidium and $P$. erecta (Vermeij \& Raben, 2009) that are a very important fisheries resources in local fisheries in Thondi Coast-Palk Bay in Tamil Nadu, India (De los Ríos et al., 2020).

\section{Material and Methods}

Collected specimens were obtained from Thondi Coast-Palk Bay in Tamil Nadu, India (944' N; $79^{\circ} 19^{\prime}$ E) in January 2009. For anatomical studies, the soft body, inside the shell was obtained by cracking open the shell. The animal was kept for relaxation in $75 \%$ magnesium chloride. Dissections were made in seawater in a dissecting dish under a stereo zoom binocular microscope. The reproductive system was studied mostly in fresh animals as the genital ducts and genital complex are more readily visible. Measurements were made with ocular and stage micrometers and the drawings were made obtained at laboratory. Only preserved animal were used to study the diminute nerves stood out prominently after fixation under direct illumination. The mean size of P. cocchlidium specimens were $98.71 \mathrm{~mm}$ and $114.29 \mathrm{~mm}$ for male and female respectively, whereas the for P. erecta were $94.28 \mathrm{~mm}$ and $106.70 \mathrm{~mm}$ for male and female respectively, 30 specimens for each sex for each species (60 specimens for species) were studied.

\section{Results}

\subsection{Digestive system}

The present study in both species the digestive system was similar with few differences in structure between each other. It consists of buccal mass, proboscis, salivary glands, stomach, intestine, rectum and anus. The digestive system of $P$. cochlidium and P. erecta is shown in (Figure 1). The proboscis in the present study, these two species showed the most conspicuous feature of the digestive system in the massive proboscis of pleuroembolic type, which is oval with two folded lips (Figure 1). In both the species the oesophagal region is extremely long and completed (Figure 1). The salivary gland in both species the salivary gland is a white mass, which surrounds the organ of oesophagus. In both the species the salivary glands are bilobed in structure. Each lobe is of the compound acinous type (Figure 1).

The stomach for both the species $P$. cochlidium and $P$. erecta the stomach is almost similar in structure. It is pale brown in colour. In two species the length and width of the stomach was measured about 53 to $60 \mathrm{~mm}$ in length in $P$. cochlidium and $75 \mathrm{~mm}$ to $80 \mathrm{~mm}$ in $P$. erecta. Internally the stomach is a simple sac with two folds. The stomach is very small, tubular, simple and U-shaped. The oesophagus is broad, opening ventrally into the posterior part of the stomach. A posterior mixing area is absent. The posterior 
oesophagus is lined with well-developed longitudinal folds. The folds on the dorsal side of the oesophagus are continuous with longitudinal folds on the outer stomach wall. The gastric chamber is subdivided into dorsal and ventral channels by a distinct and tall longitudinal fold on the inner stomach wall. The ventral channel is represented by the oesophageal groove, occupying a mid-ventral position which is continuous with the rather deep intestinal groove that is lined with tall, longitudinal, but narrow folds. The dorsal channel of the gastric chamber is lined with oblique, longitudinal folds that are much larger and more raised on the outer stomach wall (Figure 1).

The digestive gland for both species $P$. cochlidium and $P$. erecta the digestive gland is a brown coloured mass which surrounds the stomach all its length except its dorsal surface. In the two species it coils in a counter clockwise direction together with the stomach and the gonad. The duct of the digestive gland is of dichotomous branching type and opens into the stomach by way of the two apertures (Figure 1). The intestine for two species, $P$. cochlidium and P. erecta the intestine leaves the stomach at the end of the style sac region and the colour of the intestine is pale brown. It leads posterior to the oesophagus and ventrally to the heart and dorsoventrally compressed rectum. The intestinal wall is smooth bearing the major and minor typhlosoles leading out from the stomach. These are prominent features in the proximal portion of the intestine only and thereafter they gradually disappear (Figure 1). The rectum begins where the intestine is dorsoventrally flattened in both species $P$. cochlidium and P. erecta. The wall of the rectum is longitudinally folded. The anus opens into the right corner of the mantle cavity and terminates in a papilla like projection. The wall of the anus is distinctly folded into ridges and grooves. A dark brown coloured rectal gland is present near the anus (Figure 1).

\subsection{Nervous system}

The nervous system in both $P$. cochlidium and $P$. erecta is constituted by six ganglia which forms a ring the circumoesophageal ganglionic ring. The central nervous system of $P$. cochlidium and $P$. erecta consists of an oesophageal nerve ring, a visceral ganglion and two pleurovisceral connectives. The oesophageal nerve ring is formed by the fusion of several ganglia, including a pair of cerebral ganglia, pleural ganglia, pedal ganglia, buccal ganglia and a supra oesophageal ganglia. These ganglions are connected by commissures and connectives. However, the other ganglionic inner nerves were not able to be traced (Figure 2).

\subsubsection{Reproductive system}

Among the neogastropods there is a similarity in the organization of the reproductive systems. The reproductive system of various members of family melongenidae has been the subjects of several studies by virtue of their diverse modes of reproduction. The female reproductive system is more complicated than that of male. The sexes are separated in these two species in the gross morphology of the reproductive system of $P$. cochlidium and P. erecta. (Figure 3).

\subsubsection{Male reproductive system}

The male reproductive system consists of the following parts: Testis, vesicular seminalis, vas deferens, prostate gland and penis. The male reproductive system of $P$. cochlidium and P. erecta (Figure 3). Testis (Figure 3) in these two
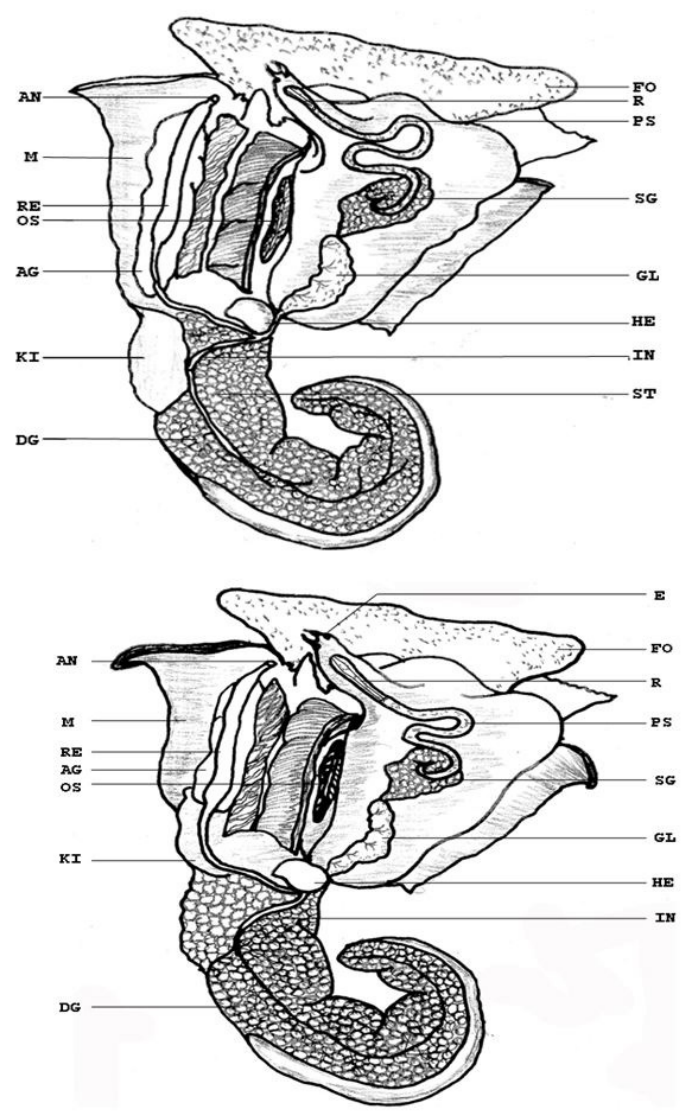

Figure 1. Digestive system in $P$. cochlidium (up) and $P$. erecta (down). Abbreviations: AG -Albumen gland; AN - Anus; DG-Digestive gland; E - Eye; FO-Foot; GL - Gill; HE - Heart; IN-Intestine; KI - Kidney; M-Mantle; OS - Osphradium ; PS-Prostate gland; R-Radula; RE - Renal duct ; SG-Salivary gland; ST- Stomach.

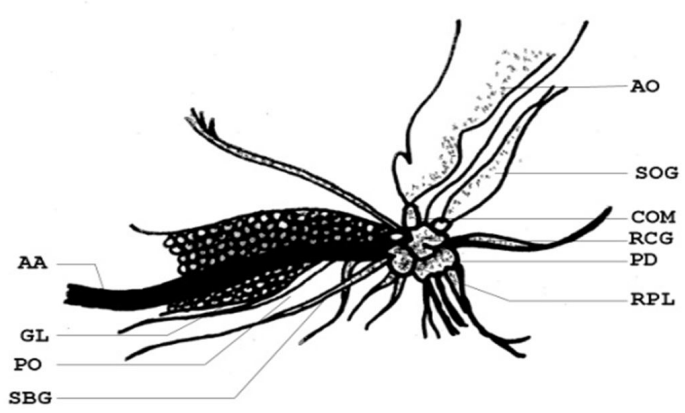

Figure 2. Nervous system of $P$. cochlidium and $P$, erecta. Abbreviations: AA - Anterior aductor; AO-Anterior oesophagus; COM- Commissure; GL -Gill; PD-Pedal Ganglion; RCG-Right Cerebral ganglion; RPL- Right Pleural Ganglion; PO-Posterior oesophagus; SOG Supra oesophageal ganglion. 

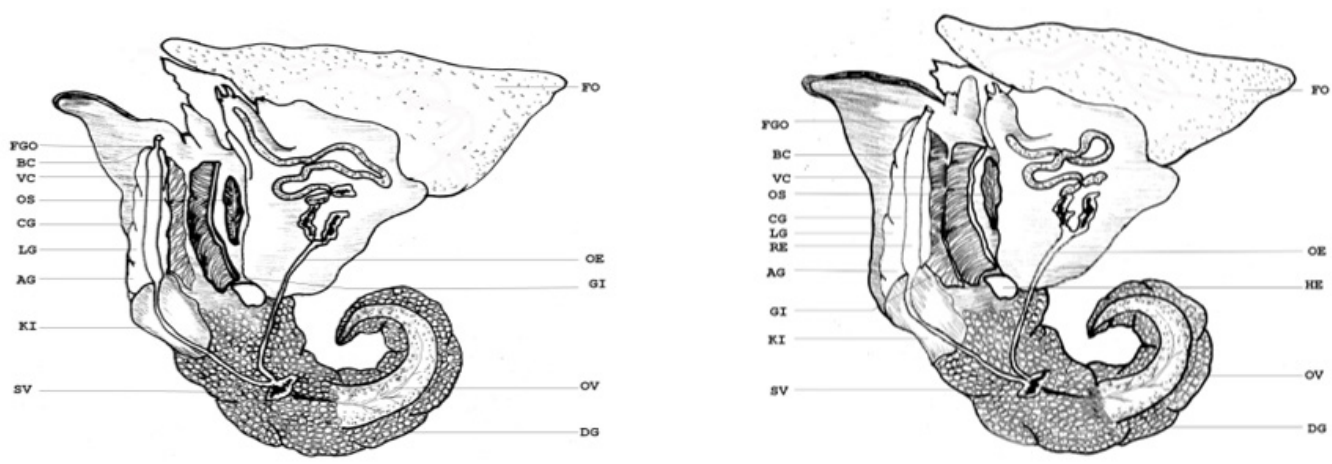

Figure 3. Reproductive system in P. cochlidium (up) and P. erecta -Male (down). Abbreviations: AG-Albumen gland; BCBursa copulatrix; CG-Capsular gland; DG-Digestive gland; FO-Foot; FGO-Front genital opening; GI-Gill; KI-Kidney; LGLeiblein gland; OE- Oesophagus; OS- Osphradium; OV-Ovary; PG- Prostate Gland; PE- Penis; RE- Renal duct; TE- Testes; VD-Vas-deferens; VS- Vesicular seminalis.

species, testis lies on the ventral surface of the visceral mass, where its tubules form a compact mass and do not ramify through the digestive gland. In fully matured condition, the colour of the testis is brick red in P. cochlidium and $P$. erecta. During the breeding season the testis occupies a greater part of the visceral mass. The testis is made up of numerous follicles, and small duct lets, which join to form a genital duct called vas deferens. The vas deferens is thrown into numerous convolusions and coils, which serve as vesicular seminalis. The noticeable differences between two species were that the testis appears to be small and shorter in $P$. cochlidium and in P. erecta it appears large and elongate. In both species, the vesicular seminalis is formed by the union of several duct lets from the globules of testis, which serves as to store the sperms during breeding season. For this purpose, it is thrown into numerous convolutions. When the sperm is packed into the vesicular seminalis, which is dull brick red in colour.

The vas deferens is situated from the testies, on the columellar side of the visceral mass in both species $P$. cochlidium and $P$. erecta the coiled vas deferens which passes anteriorly in a superficial position leads to the gut and the pericardium of the right posterior corner of the mantle cavity and it opens into the prostate gland. At this point the vas deferens lies embedded in the penis, which is situated just posterior to the right cephalic tentacles (Figure 3). The prostate gland commences at the posterior end of the pallial cavity in both species $P$. cochlidium and $P$. erecta receives in the vas deferens. Size of the prostate gland depends on the reproductive stage of the animal and it is well developed in matured animal in its breeding season (Figure 3). The vas deferens opens at the posterior end of the prostate gland which runs through it as a slit like lumen and the width of the prostate gland is uniform throughout the length until the region where it joins the vas deferens. It is well known that the prostate gland provides a liquid medium for the spermatozoa so that it could be transferred from male to female (Figure 3 ). In the present study, the penis is noted to be slightly flattened dorso ventrally and its duct is not centrally placed but lies towards the outer edge. In two species $P$. cochlidium and $P$. erecta it has a strong broad base with round coiled proximal end. The pallial vas deferens which enters the penis and its base runs through the penis towards its tip on the outer edge. The male reproductive system of $P$. cochlidium differs from that $P$. erecta in the following aspects. In $P$. cochlidium the length of the vas deferens which starts from the vesicular seminalis is slightly longer than that of $P$. erecta. The size and shape of the prostate gland is narrow and elongated in $P$. cochlidium whereas in P.erecta it is broad and short. The penis is more dorsoventrally flattened in $P$. erecta than in P. cochlidium (Figure 3).

\subsubsection{Female reproductive system}

In two species $P$. cochlidium and $P$. erecta the ovary lies in the upper part of the visceral coil, intermingling with the digestive gland. In a fully matured animal the ovary occupies $1 / 3$ of the visceral coil. The structure, position and colour of the ovary are similar in $P$. cochlidium and $P$. erecta (Figure 3 ). In both species the oviducts spreads over the surface of the digestive gland in the visceral mass and from it, a thin walled oviduct leads forwards and ventrally on the right side of the viscera. The junction of oviduct with the albumen gland is characterized with the presence of another duct called the gonopericardial duct. The gonopericardial duct opens into the wall of the pericardium and near the opening, it is thick and muscular. The oviduct in two species joins with the albumen gland on its ventral aspects (Figure 3). In two species albumen glands, $P$. cochlidium and $P$. erecta the first and posterior most part of the pallial oviduct has an albumen gland into which the visceral oviduct opens. The albumen gland is an inverted ' $U$ ' shaped loop like structure with the two arms close to each other. It is pale yellow in colour. The oviduct opens into the first distal limp of the capsular gland and its opening is guarded by sphincter muscles which may regulate the passage effects. The albumen gland opens into the posterior ventral wall of the capsule gland on the right side of the ventral channel (Figure 3). In between 
the intestine gland a thick blackish brown colour strip like structure is present which is called ingesting gland. This gland communicates with the ventral canal. In P. erecta, this gland occupies more area than in $P$. cochlidium. In $P$. erecta, the dorsal part of this gland is more elevated, and its base is narrow, whereas in $P$. cochlidium there is a broad base and not that much elongated dorsal part (Figure 3). In two species the capsular gland leads forward on the right side of the mantle cavity and on dissection it can be seen as an opaque white or yellowish mass which is divided into right and left glandular lobes. These lobes are joined dorsally and ventrally by a comparatively thin and narrow wall forming a dorsal and ventral suture. Throughout the length of the capsular gland a channel called ventral channel runs on the ventral aspects of the ventral channel gland which is a closed duct. Posteriorly the ventral channels lead to the duct of the ingesting gland and receptaculum seminalis and anteriorly to the bursa copulatrix (Figure 3). In general, organization of the male and female reproductive system of $P$. cochlidium and $P$. erecta follows the same general neogastropod pattern. The bursa copulatrix is in the proximal part of the pallial oviduct situated ventrally. It is a pouch like structure which receives the sperm along with prostatic secretion during copulation. It is connected with the ventral channel on its posterior end.

\section{Discussion}

\subsection{Digestive organs}

The mouth is over hung by the outer muscular rim of the peristomal rim, which is very similar to $U$. cinerea (Carriker, 1943). In P. cochlidium the proboscis measures about 8 to $10 \mathrm{~cm}$ in length and 0.2 to $0.5 \mathrm{~cm}$ in width and in $P$. erecta it was measured about 7 to $10 \mathrm{~cm}$ in length and 0.3 to $0.5 \mathrm{~mm}$ in width. In both forms the colour of the proboscis is white. The odontophore and radular sac lies within the proboscis. The odonotophore is composed of the retractor muscles, cartilaginous rod and the radular sac. The proboscis in P. cochlidium and P. erecta are similar to the description of the proboscis and this similar observation has been made by Tagore (1989) in Thais species and Thais haemastoma (Linnaeus, 1767) by Roller et al. (1984).

It is most conveniently divided into 3 parts, the anterior, mid and posterior oesophagus (Graham, 1941, 1949). The anterior oesophagus begins above the opening of the radular sac. Its dorsal folds are the continuations of the prominent dorsal folds of the wall of the buccal cavity. The mid oesophagus can be subdivided into two portions on the basis of structural differences in the organ of nerve ring portion and the convoluted portion. Posterior and mid oesophagus becomes extremely narrow and slightly turned to the left side of the median axis (Figure 1). The posterior oesophagus is slender and long. The junction where the mid oesophagus joins with the posterior oesophagus is marked by a constriction along with the reduction in diameter of posterior oesophagus. These glands of paired salivary gland and accessory salivary gland are associated with the oesophagus, which opens into the mid oesophagus.
The position and shape of the lobes are closely related to the Muricid gastropod Druparicina (Wu, 1965a, b, 1973). The ducts of salivary glands are dichotomously branched and all the branches united to form a single tube.

The stomach was similar with descriptions of Thais sp. by Tagore (1989), in C. ramosus by Middlefart (1992a, b) and Stella (1995) in Chicoreus species and Ravichandran (2012) in Ch. ponderosus. The openings of the ducts of the digestive glands are large and oval. The anterior opening is located just anterior and ventral to the transverse fold, while the posterior one lies at the entrance of the oesophagus into the stomach. Duct pouches are not prominent and the typhlosoles are poorly defined. Tan and Phuah (1999) examined the feeding of the species of $P$. cochlidium in Singapore. The observations of digestive organs, are similar with descriptions of Thais sp. by Tagore (1989), in C. ramosus (Linnaeus, 1758) by Middlefart (1992a, b) and Stella (1995) in Chicoreus species and Ravichandran (2012) in C. ponderosus, P. tupiniquim (Abbate and Simone, 2015), Thaisella guatemalteca (Simone, 2017), and Tudicla spirillus (Linnaeus, 1767) (Harasewych, 2018).

\subsection{Nervous system}

The present results about nervous system anatomy are similar with descriptions made by Stella (1995) in Chicoreus species and Ravichandran (2012) in C. ponderosus, Rapana venosa (Valenciennes, 1846) (Guohua et al., 1990), P. tupiniquim (Abbate and Simone, 2015), Thaisella guatemalteca (Simone, 2017), and Tudicla spirillus (Linnaeus, 1767) (Harasewych, 2018).

\subsection{Reproductive organs}

The general scheme is similar with observations in Nucella lapillus (Linnaeus, 1758) and Oceanebra crinacea (Linnaeus, 1758) by Fretter (1941) and Stella (1995) in Chicoreus species and Ravichandran (2012) in $C$. ponderosus $P$. tupiniquim (Abbate and Simone, 2015), T. guatemalteca (Simone, 2017), and T. spirillus (Linnaeus, 1767) (Harasewych, 2018). This similar observation for male reproductive organs has been made in N. lapillus and O. crinacea by Fretter (1941) and Stella (1995) in Chicoreus species and Ravichandran (2012) in C. ponderosus P. tupiniquim (Abbate and Simone, 2015), T. guatemalteca (Simone, 2017), and T. spirillus (Linnaeus, 1767) (Harasewych, 2018). Whereas for female reproductive organs there are similarities with descriptions of Tagore (1989) in Thais sp. Stella (1995) in Chicoreus species and Ravichandran (2012) in C. ponderosus P. tupiniquim (Abbate and Simone, 2015), T. guatemalteca (Simone, 2017), and T. spirillus (Linnaeus, 1767) (Harasewych, 2018).

The male and female reproductive system of two species agree well with the description given by Fretter (1941) for N. lapillus, Tagore (1989) for Thais sp. and Stella (1995) for Chicoreus sp and Ravichandran (2012) in C. ponderosus P. tupiniquim (Abbate and Simone, 2015), T. guatemalteca (Simone, 2017), and Tudicla spirillus (Linnaeus, 1767) (Harasewych, 2018). In male, the prostate gland is a closed one which is slightly broader in diameter in $P$. cochlidium 
and in P. erecta. In these two species it is basically organized on the same plan. In female the capsular gland is obvious because of the similar mode of reproduction and production of attached egg capsule.

In summary, the exposed results of soft body anatomy of $P$. cochlidium and $P$. erecta is similar to other gastropods species, and these results would be important for other basic and applied studies about both species that are an important fisheries resource.

\section{Acknowledgements}

The present study was founded by project MECESUP UCT 0804, and the authors express the gratitude to M.I. and S.M.A for their valuable comments for improve the manuscript. The authors express their thankfulness to the financial support for this research work under RUSA-Phase 2.0 scheme, Govt of India.

\section{References}

ABBATE, D. and SIMONE, L.R.L., 2015. Review of Pugilina from the Atlantic, with description of a new species from Brazil (Neogastropoda: melongenidae). African Invertebrates, vol. 56, no. 3, pp. 559-577. http://dx.doi.org/10.5733/afin.056.0305.

ANDREWS, E.B., 1991. The fine structure and function of the salivary glands of Nucella lapillus (Gastropoda: muricidae). The Journal of Molluscan Studies, vol. 57, no. 1, pp. 111-126. http:// dx.doi.org/10.1093/mollus/57.1.111.

BALL, A.D., ANDREWS, E.B. and TAYLOR, J.D., 1997. The ontogeny of the pleurembolic proboscis in Nucclla lapillus (Gastropoda: muricidae). The Journal of Molluscan Studies, vol. 63, no. 1, pp. 87-99. http://dx.doi.org/10.1093/mollus/63.1.87.

BENNY, A., VENMATHIAMARAN, B.A. and AYYAKKANNU, K., 1996. Food and feeding habits of Hemifusus pugilinus (Gastropoda: Melongenidae). Phuket Marine Biological Center Special Publication, vol. 17, no. 1, pp. 273-278.

BHANU, R.C., SHYAMASUNDARI, K. and RAO, K.H., 1981. Histological and histochemical studies on the salivary gland of Thais bufo (Lamarck) (Mollusca: Neogastropoda). Monitore Zoologico Italiano, vol. 15, no. 4, pp. 239-247.

BHANU, R.C., SHYYAMASUNDARI, K. and RAO, K.H., 1982. Histological and histochemical studies on the albumen gland and capsular gland of Thais bufo (Lamarck) (Mollusca: Gastropoda). Proceedings: Animal Sciences, vol. 91, no. 5, pp. 407-415. http:// dx.doi.org/10.1007/BF03186136.

BROWN, S.C., 1969. The structure and function of the digestive system of the mud snail Nassarius obsoletus (Say). Malacologia, vol. 9, no. 2, pp. 447-500.

CANTILLANEZ, M. and AVENDAÑO, M., 2013. Role of temperature in the reproductive cycle of Thais chocolate (Gastropoda, muricidae) in Chanavaya, Tarapaca, Chile. Latin American Journal of Aquatic Research, vol. 41, no. 5, pp. 854860. http://dx.doi.org/10.3856/vol41-issue5-fulltext-6.

CANTILlÁNEZ, M., AVENDAÑO, M., ROJO, M. and OLIVARES, A., 2011. Reproductive and population parameters of Thais chocolata (Ducos, 1832) (Gastropoda, Thaididae) in La Rinconada marine reserve, Antofagasta, Chile. Latin American
Journal of Aquatic Research, vol. 39, no. 3, pp. 499-511. http:// dx.doi.org/10.3856/vol39-issue3-fulltext-10.

CARRIKER, M.R., 1943. On the structure and function of the proboscis in the common oyster drill, Urosalpinx cinerea Say. Journal of Morphology, vol. 73, no. 3, pp. 441-506. http://dx.doi. org/10.1002/jmor.1050730304.

CARRIKER, M.R., 1981. Shell penetration and feeding by Naticacean and Muricacean predatory gastropods: a synthesis. Malacologists., vol. 20, no. 2, pp. 403-422.

CARRIKER, M.R., VAN ZANDT, D. and CHARLTON, G., 1967. Gastropod Urosalpinx: $\mathrm{pH}$ of accessory boring organ while boring. Science, vol. 158 , no. 3803, pp. $920-922$. http://dx.doi. org/10.1126/science.158.3803.920. PMid:17753604.

CARRIKER, M.R. and WILLIAMS, L.G., 1978. The chemical mechanism of shell dissolution by predatory boring gastropods: a review and an hypothesis. Malacologia, vol. 17, pp. 143-156.

CARRIKER, M.R., SCOTT, D.B. and MARTIN, G.N., 1963. Demineralization mechanism of boring gastropods. In: R. F. SOGNANNAES, ed. Mechanisms of hard tissue destruction. Washington: American Association for the Advancement of Science, pp. 55-89.

CHÉTATL, M. and FOURNIÉ, J., 1969. Shell-boring mechanism of the gastropod Purpura (Thais) lapillus: a physiological demonstration of the role of carbonic anhydrase in the dissolution of $\mathrm{CaCO}_{3}$. American Zoologist, vol. 9, no. 3, pp. 983-990. http:// dx.doi.org/10.1093/icb/9.3.983

DE LOS RIOS, P., KANAGU, L., LATHASUMATHI, C.H. and STELLA, C., 2020. Age and growth of two populations of Pugilinia cochlidium (Gastropoda: Melongenidae), from Thondi coast- Palk Bay in Tamil Nadu-South East coast of India. Brazilian Journal of Biology $=$ Revista Brasileira de Biologia, vol. 80, no. 1, pp. 158-166. http://dx.doi.org/10.1590/1519-6984.203544. PMid:31576930

FRETTER, V., 1941. The genital ducts of some British Stenoglossan Prosobranchs. Journal of the Marine Biological Association of the United Kingdom, vol. 25, no. 1, pp. 173-211. http://dx.doi. org/10.1017/S0025315400014375.

FRETTER, V. and GRAHAM, A., 1962. British prosobranch molluscs: their functional anatomy and ecology. London: The Ray Society.

GALLARDO, C.S. and GARRIDO, O.A., 1989. Spermiogenesis and sperm morphology in the marine gastropod Nucella crassilabrum with an account of morphometric patterns of spermatozoa variation in the family Muricidae. Invertebrate Reproduction \& Development, vol. 15, no. 3, pp. 163-170. http://dx.doi.org/10.1 080/07924259.1989.9672039.

GRAHAM, A., 1941. The oesophagus of the stenoglossan prosobranchs. Proceedings of the Royal Society of Edinburgh, vol. 61, no. 1, pp. 1-32. http://dx.doi.org/10.1017/S0080455X00011322.

GRAHAM, A., 1949. The molluscan stomach. Transactions of the Royal Society of Edinburgh, vol. 61, no. 3, pp. 737-761. http:// dx.doi.org/10.1017/S008045680001913X.

GREENE, J. and KOHN, A.J., 1989. Functional morphology of the Conus proboscis (Mollusca: gastropoda). Journal of Zoology, vol. 219, no. 3, pp. 487-493. http://dx.doi.org/10.1111/j.1469-7998.1989. tb02595.x. 
GUOHUA, L., JIMIN, C., QIUYU, W., LIN, H. and SHENGTAO, H., 1990. Anatomy the nervous system of Rapana venosa. Acta Zoologica Sininca Dongwu, vol. 36, pp. 345-351.

HARASEWYCH, M.G., 1984. Comparative anatomy of four primitive muricacean gastropods: Implications for Trophonine phylogeny. American Malacological Bulletin, vol. 3, no. 1, pp. 11-26.

HARASEWYCH, M.G., 2018. The anatomy of Tudicla spirillus (Linnaeus, 1767) and the relationships of the Tudiclidae (Gastropoda: neogastropoda). The Nautilus, vol. 132, no. 2, pp. 35-44.

HAWKINS, L.E. and HUTCHINSON, S., 1988. Egg capsule structure and hatching mechanism of Ocenebraerinacea $(\mathrm{L})$ (Prosobranchia: muricidae). Journal of Experimental Marine Biology and Ecology, vol. 119, no. 3, pp. 269-283. http://dx.doi. org/10.1016/0022-0981(88)90197-9.

HOU, S., CHENG, J., HOU, L., WANG, Q. and GUOHUA, L., 1990. Morphology of reproductive system of Rapana venosa (Valenciennes) (Gastropoda). Acta Zoologica Sininica, vol. 36, no. 4, pp. 398-405.

HOUSTON, R.S., 1971. Reproductive biology of Thais emarginata and Thais canaliculate (Duclos 1832). The Veliger, vol. 13, pp. 348-357.

HOUSTON, R.S., 1976. The structure and function of neogastropod reproductive systems: with special reference to Columbella fuscata Sowerby, 1832. The Veliger, vol. 19, pp. 27-46.

JARAMILLO, R., 1991. Female genital system of Chorus giganteus (Prosobranchia: muricidae). The Veliger, vol. 34, pp. 297-301.

KANTOR, Y.I. and HARASEWYCH, M.G., 1994. The diet of Pisaniatincta (Gastropoda: Buccinidae) in Eastern Florida. The Veliger, vol. 37, pp. 119-120.

KANTOR, Y.I., 1996. Phylogeny and relationships of Neogastropoda. In: J. D. TAYLOR, ed. Origin and evolutionary radiation of the mollusca. Oxford: Oxford University Press, pp. 221-230.

KANTOR, Y.I. and TAYLOR, J.D., 2002. Foregut anatomy and relationships of raphitomine gastropods (Gastropoda: Conoidea: Raphitominae). In: M. OLIVERIO and R. CHEMELLO, eds. Systematics, phylogeny and biology of Neogastropoda (Bolletino Malacologico, No. 5). Napoli: Società Italiana di Malacologia, pp. 161-174.

KANTOR, Y.I. and TURSCH, B., 2001. Feeding of Oliva. In: B. and TURSCH and D. GREIFENEDER, eds. The genus Oliva and the species problem. Costa Rica: L'Informatore Piceno and Bosque BMT, S.A., pp. 209-216

KOHN, A.J., 1983. Feeding biology in gastropods. In: A. S. M. SALEUDDIN and K. M. WILBUR, eds. The Mollusca, Physiology. London: Academic Press, pp. 1-63. http://dx.doi. org/10.1016/B978-0-12-751405-5.50009-9.

LUS, V.Y., 1981. New species of Tacita (Prosobranchia, Buccinidae) with wide distribution in the north-western part of Pacific Ocean. Proceedings of the Institute of Oceanology of Russian Academy of Sciences, vol. 115, pp. 140-154.

MARCUS, E. and MARCUS, E., 1962a. On Leucozonia nassa. Boletim da Faculdade de Filosofia, Ciências e Letras, Universidade de São Paulo. Zoologia, vol. 24, no. 24, pp. 11-30. http://dx.doi. org/10.11606/issn.2526-3382.bffclzoologia.1962.120568.

MARCUS, E. and MARCUS, E., 1962b. Studies on Columbellidae. Boletim da Faculdade de Filosofia, Ciências e Letras, Universidade de São Paulo. Zoologia, vol. 24, no. 24, pp. 335-402. http:// dx.doi.org/10.11606/issn.2526-3382.bffclzoologia.1962.120597.
MCLEAN, N., 1971. On the function of the digestive gland in Nassarius. The Veliger, vol. 13, pp. 273-274.

MEDINSKAYA, A.I., 1992. Anatomy of the proboscis walls in Neogastropoda (Gastropoda) and its connection with diet and feeding mechanism. Ruthenica, vol. 2, no. 1, pp. 27-35.

MEDINSKAYA, A.I., 1993. Anatomy of the stomach of some Neogastropoda from the offshore zone of the Japan Sea. Ruthenica, vol. 3, no. 1, pp. 17-24.

MEDINSKAYA, A.I., 1999. New data on the stomach of turriform gastropods (Gastropoda, Conoidea). Ruthenica, vol. 9, no. 2, pp. 95-99.

MERDSOY, B. and FARLEY, J., 1973. Phasic activity in the digestive gland cells of the marine prosobranch gastropod, Littorina littorea (L.). Proceedings of the Malacological Society of London, vol. 40, no. 6, pp. 474-482. http://dx.doi.org/10.1093/ oxfordjournals.mollus.a065242.

MIDDLEFART, P., 1992a. Morphology and anatomy of Chicoreus ramosus (Linnaeus, 1758) soft part. Phuket Marine Biology Center Special Publication, vol. 11, pp. 66-71.

MIDDLEFART, P., 1992b. Morphology and anatomy of Chicoreus brunneus (Link, 1807) description of shell and soft part. Phuket Marine Biology Center Special Publication, vol. 11, pp. 54-60.

NYLEN, M.U., PROVENZA, D.V. and CARRIKER, M.R., 1969. Fine structure of the accessory boring organ of the gastropod Urosalpinx. American Zoologist, vol. 9, no. 3, pp. 935-965. http:// dx.doi.org/10.1093/icb/9.3.935.

PERSON, P., SMARSH, A., LIPSON, S.J. and CARRIKER, M.R., 1967. Enzymes of the accessory boring organ of the muricid gastropod Urosalpinx cinerea follyensis. I. Aerobic and related oxidative systems. The Biological Bulletin, vol. 133, no. 2, pp. 401-410. http://dx.doi.org/10.2307/1539835. PMid:4294119.

PONDER, W.F., 1968. Anatomical notes on two species of the Colubrariidae (Mollusca, Prosobranchia). Transactions of the Royal Society of New Zealand: Zoology, vol. 10, pp. 217-223.

PONDER, W.F., 1970. The morphology of Alcithoe arabica (Mollusca: volutidae). Malacological Review, vol. 3, pp. 127-165.

PONDER, W.F., 1973. The origin and evolution of the Neogastropoda. Malacologia, vol. 12, no. 2, pp. 295-338. PMid:4788271.

PURCHON, R.D., 1968. The biology of the molluscs. Oxford: Pergamon Press.

RAVICHANDRAN, R., 2012. Taxonomy and biology of Chicoreus species (Class: Bivalvia: Family: Muricidae) from Thondi coast - Palk Bay in Tamil Nadu. Kairakudi: Alagappa University, 120 p. PhD Thesis.

ROLLER, R.A., GARTON, D.W. and STICKLE, W.B., 1984. Regeneration of the proboscis, radula and odontophoral cartilage of the southern oyster drill Thais haemastoma canaliculata (Gray) (Prosobranchia: Muricidae) after amputation. American Malacological Bulletin, vol. 2, pp. 63-73.

SIMONE, L.R.L., 2017. A new species of Thaisella (Neogastropoda: Muricidae) from Caribbean Guatemala, with accounts on the anatomy and taxonomy of the genus in the western Atlantic. Archiv für Molluskenkunde, vol. 146, no. 1, pp. 111-120. http:// dx.doi.org/10.1127/arch.moll/146/111-120.

SMITH, B.S., 1967. The Neogastropod stomach, with notes on the digestive diverticula and intestine. Transactions of the Royal 
Society of Edinburgh, vol. 67, no. 2, pp. 23-42. http://dx.doi. org/10.1017/S0080456800023863.

SMITH, B.S., 1980. The estuarine mud snail, Nassariusos boletus; Abnormalities in the reproductive system. The Journal of Molluscan Studies, vol. 46, pp. 247-256.

SMITH, B.S., 1981. Male characteristic in the female Nassariusos boletusvariation related to locality season and year. The Veliger, vol. 23, pp. 212-216.

STELLA, C., 1995. Studies on the taxonomy and ecobiology of Chicoreus species from Parangipettai waters, South East Coast of India. Chidambaram: Annamalai University, 195 p. Ph.D. Thesis.

STEPHEN, J. and BLABER, M., 1970. The occurrences of a Penis- like out growth behind the right tentacle in spent females of Nucella lapillus. Malacological Society of London, vol. 39, pp. 231-233. http://dx.doi.org/10.1093/oxfordjournals.mollus.a065097.

TAGORE, J., 1989. Studies on the Thaisids Thais biserialis and Thais bufo from the Tranquebar rocky shore (South East Coast of India). Chidambaram: Annamalai University, 212 p. Ph.D. Thesis.

TAN, K.S. and PHUAH, C.L., 1999. Diet and feeding habits of Pugilina cochlidium (Neogastropoda: Melongenidae) in Singapore. The Journal of Molluscan Studies, vol. 65, no. 4, pp. 499-501. http://dx.doi.org/10.1093/mollus/65.4.499.

TAYLOR, J.D., 1978. Habitats and diet of predatory gastropods at Adoll, Maldives. Journal of Experimental Marine Biology and
Ecology, vol. 31, no. 1, pp. 83-103. http://dx.doi.org/10.1016/00220981(78)90138-7.

TAYLOR, J.D., KANTOR, Y.I. and SYSOEV, A.V., 1993. Foregut anatomy, feeding mechanisms, relationships and classification of Conoidea (Toxoglossa) (Gastropoda). Bulletin of the Natural History Museum. Zoology Series, vol. 59, no. 2, pp. 125-169.

TAYLOR, J.D., MORRIS, N.J. and TAYLOR, C.N., 1980. Food specialization and the evolution of predatory prosobranch gastropods. Palaeontology, vol. 23, no. 2, pp. 375-409.

WARD, J., 1965. The digestive tract and its relation to feeding habits in' the stenoglossan prosobranch Coralliophila abbreviate (Lamarck). Canadian Journal of Zoology, vol. 43, no. 3, pp. 447-464. http://dx.doi.org/10.1139/z65-045. PMid:14314948.

WU, S.K., 1965a. Comparative functional studies of the digestive system of the Muricid gastropods. Druparicina and Morula granulata. Malacologia, vol. 3, pp. 211-233.

WU, S.K., 1965b. Studies of the radulae of Taiwan Muricid Gastropods. Bulletin of the Institute of Zoology, Academia Sinica, vol. 4, pp. 95-106.

WU, S.K., 1973. Comparative studies on the digestive and reproductive systems of some Muricid gastropods. Bulletin of the American Malacological Union, vol. 1973, pp. 1. 